\title{
The effects of defective nutrition during pregnancy in farm livestock
}

\author{
By K. L. Blaxter, Hannah Dairy Research Institute, Kirkhill, Ayr
}

The extent of the loss of life and productivity associated with the breeding of farm livestock is summarized in Table I and shows that in farm stock the stillbirth rate is usually much higher than that in man and that animal infant mortality exceeds human infant mortality by a factor of at least four, and usually ten. Furthermore, in animals maternal mortality rates, particularly in sheep, grossly exceed the maternal mortality rate in human populations.

\section{Table I. Infantile and maternal mortality in animals and man}

\begin{tabular}{|c|c|c|c|c|c|}
\hline Species & Area & $\begin{array}{l}\text { Stillbirth } \\
\text { rate } \\
(\%)\end{array}$ & $\begin{array}{l}\text { Infant } \\
\text { mortality } \\
\text { rate } \\
(\%)\end{array}$ & $\begin{array}{l}\text { Maternal } \\
\text { mortality } \\
\text { rate } \\
(\%)\end{array}$ & Reference \\
\hline $\begin{array}{l}\text { Man } \\
\text { Pig }\end{array}$ & $\begin{array}{l}\text { Scotland } \\
\text { England }\end{array}$ & $\begin{array}{c}2 \cdot 5 \\
2 \cdot 2-6 \cdot 4\end{array}$ & $\begin{array}{c}I \cdot 9 \\
23-3 I\end{array}$ & 0.1 & $\begin{array}{l}\text { Smith (1954) } \\
\text { Braude, Clarke \& } \\
\text { Mitchell (1954-5) } \\
\text { Perry (1956) }\end{array}$ \\
\hline Sheep* & $\begin{array}{l}\text { N. Ireland } \\
\text { Scotland } \\
\text { England }\end{array}$ & $\frac{4 \cdot 9}{3 \cdot 3}$ & $\begin{array}{l}13 \\
15-26 \\
-\end{array}$ & - & $\begin{array}{l}\text { Gracey (1955) } \\
\text { Gill \& Thomson (1954) } \\
\text { Sellers \& Leech (1955) }\end{array}$ \\
\hline Cattle & $\begin{array}{l}\text { Scotland } \\
\text { England }\end{array}$ & $\begin{array}{l}6.4 \\
6.6\end{array}$ & $\begin{array}{r}\text { II.1 } \\
6 \cdot 0\end{array}$ & $\begin{array}{c}\text { Less than } \\
1 \%\end{array}$ & Withers (1952, 1955) \\
\hline
\end{tabular}

* The values vary considerably according to the type of sheep farming. Even when large numbers of flocks are investigated the stillbirth rate may be as high as $10 \%$ (Williams, 1954-5), and the death rate of ewes can approach $30 \%$ (Sellers \& Leech, 1955). Similarly, losses of lambs in the first weeks of life on hill farms in bad winters often grossly exceed, by a factor of 5 , the losses on lowland farms.

Some of this loss of life is due to communicable disease of either the mother or the newborn; some is due to accident as instanced by the crushing to death of one or more of her babies by the sow when she lies to suckle them. How much can be referred to faulty nutrition of the dam during pregnancy is not known.

Several rather spectacular nutritional diseases result when the maternal diet is deficient in a particular nutrient, and under specialized conditions of farm husbandry such diseases can assume epizootic proportions. Nevertheless, in their contribution to the total losses given in Table $\mathrm{I}$, deficiencies of single mineral elements or of vitamins probably only play a secondary part. A major nutritional cause of low reproductive performance, in its widest sense, is the supply of insufficient food energy to the pregnant animal. The effects of insufficient food energy were recognized and attributed to poor nutrition during pregnancy by farmers more than 100 years ago (Mc'Turk, 1843), but most of the quantitative data refer to modern experiments in which different 'nutritional planes' have been adopted. The primary deficiency in such experiments is one of net calories.

The extent of the undernutrition with respect to energy during pregnancy which occurs in farm stock under practical conditions in Britain depends on the availability and nutritive value of the food supply and on the physical demand made on 
the pregnant animal by the physical environment. There is one physiological factor which needs consideration as well, namely that the appetite of the pregnant ruminant declines as pregnancy advances. During late pregnancy the gravid uterus occupies considerable space in the abdominal cavity, exerts a pressure on the alimentary tract, and consequently appetite falls. In the last fifth of pregnancy voluntary intake of food drops by 20-40\% (Mäkelä, 1956; Gordon \& Tribe, I95I). Very fat cows suffer an even greater diminution in voluntary food intake during pregnancy than more normal ones, since their abdominal cavities may contain up to 251 . fat (Paloheimo, r944). Fat ewes also suffer a considerable reduction in appetite, presumably for the same reason (Gordon \& Tribe, I951).

In hill sheep in Britain, undernutrition during pregnancy can be extreme. First, the availability of food is poor, and the ewe must expend energy in searching for it in snow and ice conditions. Secondly, the nutritive value of the food per unit bulk is low, and the large proportion of indigestible material it contains places a purely physical limit on appetite. This is quite apart from the fact that the ewe's appetite for food falls. A further consideration is that low environmental temperatures and high winds must have some effect on the energy requirement. We have found the critical temperature of shortly-clipped sheep even when fed at the maintenance level to be $28-30^{\circ}$ (Blaxter, Graham \& Wainman, 1956), and it is questionable whether a wet fleece in a high wind really affords the ewe much insulation and protection. It is little wonder that the $100 \mathrm{lb}$. hill ewe may lose 20 or $30 \mathrm{lb}$. in weight during pregnancy: what is remarkable is that she can produce live twin lambs at the end of such a physical and nutritional ordeal.

With cattle, comparable blatant undernutrition of the pregnant animal is not commonplace in Britain, though it is found in pastoral countries experiencing severe drought conditions during the winter months.

\section{Fecundity and energy supply}

Underfeeding in the sheep does not delay the onset of the breeding season, in terms of the onset of ovulation, but shortens the cycle length and more silent heats occur (Hafez, I952; Wallace, 1954-5). The conception rate may be lowered by as much as $75 \%$. In cattle both Joubert (1954-5) and Asdell (1952) found that low levels of nutrition had little effect on conception rates once oestrus was manifest, much the same number of services being required per conception in normal and in underfed groups. The effect of undernutrition in cattle appears to reside in the failure to exhibit oestrus. This is important since undernutrition in pregnancy results in a delay of postpartum oestrus (Joubert, 1954-5; Du Toit \& Bisschop, 1929), and a slowing of the rate of reproduction. In sheep, which breed seasonally, poor nutrition in the previous pregnancy is usually cancelled by better nutrition during the anoestrous period of the summer months.

\section{Energy nutrition, and foetal mortality and morbidity}

Many experiments with both cattle and sheep have been carried out in which one group of animals has been subjected to a low nutritional plane and another to a high 
Table 2. Pooled results of the experiments at Cambridge (Wallace, 1948) and at Aberdeen (Thomson $\mathbb{E}$ Thomson, 1948-9) showing the effect of low levels of feeding during pregnancy on reproductive performance

$\begin{array}{lcccc} & \text { Lambs } & \begin{array}{c}\text { Lambs that } \\ \text { died shortly } \\ \text { after birth }\end{array} & \begin{array}{c}\text { Lambs that } \\ \text { survived } \\ (\%)\end{array} \\ \text { High plane of nutrition } & \text { No. of lambs } & (\%) & (\%) & 91 \cdot 4 \\ \text { Low plane of nutrition } & 58 & 5 \cdot 2 & 3 \cdot 4 & 45 \cdot 3\end{array}$

one. In Table 2, the results from several such experiments in Britain have been combined. The results for low-plane ewes do not refer to an unlikely extreme of dietary abuse, but to rations which result in reductions in the weight of the ewe during the last 6 weeks of pregnancy of a few lb. only. From the evidence available the stillborn deaths are probably not foetal deaths in utero but deaths that occur during the process of parturition.

There are several factors associated with the high stillbirth rate and the high mortality immediately following birth which are referable to the nutritional status of the ewe at the time of birth. On low planes of nutrition, particularly in ewes bearing twins, uterine inertia and general exhaustion during and following parturition probably contribute to the stillbirth rate.

\section{Energy nutrition and birth weight}

The mean weights of lambs born to ewes given different amounts of food energy during pregnancy show an increasing gradation of effect from birth weights of $5 \mathrm{lb}$. to $13 \mathrm{lb}$. Table 3 summarizes results obtained experimentally with cattle in Britain

Table 3. Effect of the plane of nutrition before parturition on the birth weight of cattle

\begin{tabular}{|c|c|c|c|c|}
\hline \multirow[b]{2}{*}{ Country } & \multicolumn{2}{|c|}{$\begin{array}{l}\text { Daily weight gain of cow } \\
\text { in last } 6 \text { weeks of } \\
\text { pregnancy (lb.) }\end{array}$} & \multicolumn{2}{|c|}{$\begin{array}{l}\text { Birth weight } \\
\text { of calf (lb.) }\end{array}$} \\
\hline & $\begin{array}{l}\text { High level } \\
\text { of nutrition }\end{array}$ & $\begin{array}{l}\text { Low level } \\
\text { of nutrition }\end{array}$ & $\begin{array}{l}\text { High level } \\
\text { of nutrition }\end{array}$ & $\begin{array}{l}\text { Low level } \\
\text { of nutrition }\end{array}$ \\
\hline South Africa & & & & \\
\hline $\begin{array}{l}\text { (Joubert, 1954-5) } \\
\text { England }\end{array}$ & 0.47 & 0.17 & $63 \cdot 3$ & $55^{\cdot 8}$ \\
\hline $\begin{array}{l}\text { (Blaxter, 1944) } \\
\text { South Africa }\end{array}$ & $2 \cdot 48$ & 0.37 & $83 \cdot 7$ & $79 \cdot 6$ \\
\hline $\begin{array}{l}\text { (Bonsma, 1949) } \\
\text { England }\end{array}$ & & & $65 \cdot 0^{*}$ & $52 \cdot 0^{*}$ \\
\hline (Braude \& Walker, r949) & & & $87.0+$ & $79 \cdot 9 \dagger$ \\
\hline
\end{tabular}

and South Africa, together with practical observations on birth weights in those countries under both good and poor nutritional circumstances. The results show that birth weight in cattle also reflects maternal nutrition, though perhaps not to the 
degree noted in sheep. It is doubtful whether such extremes of dietary manipulation were used in the experiments with cattle as in those with sheep.

\section{Energy nutrition and foetal development}

The question arises: Are these offspring from underfed mothers normally developed for their chronological age and merely undersized, or does their development conform to that found at an earlier stage of embryonic growth in normally nourished individuals?

The most complete data relevant to this point are those of Wallace (r948) based on his studies with sheep. Earlier work giving comparable results is that of Hammond (1932) and of Verges (1939). Wallace concluded from his work that 'not only does competition for available nutrients exist between the foetus and its mother when these are in short supply but . . . some tissues and organs are penalized more than others'.

The extent to which undernutrition affects development of the foetus at birth may be assessed by comparing the weights of the tissues of the undersized full-term lambs from undernourished ewes with the weights of foetuses of different ages from mothers adequately fed. This comparison gives an approximation to the degree of retardation of the growth of various tissues. Results of a graphical analysis of Wallace's results are given in Table 4. The data show that in Wallace's experiments

Table 4. Estimates of the 'prematurity' of lambs from ewes underfed during the latter part of pregnancy*

\begin{tabular}{|c|c|c|c|}
\hline & Tissue or organ & $\begin{array}{c}\text { Foetal age } \\
\text { estimated from } \\
\text { weight of tissue } \\
\text { or organ (days) }\end{array}$ & $\begin{array}{c}\text { Maturity } \phi, \\
\text { estimated foetal age } \\
\begin{array}{c}\text { actual age } \\
(\%)\end{array}\end{array}$ \\
\hline $\begin{array}{l}\text { Tissues and organs } \\
\text { growing at the same } \\
\text { rate as the body as a } \\
\text { whole }\end{array}$ & $\begin{array}{l}\text { Total body } \\
\left\{\begin{array}{l}\text { Muscle } \\
\text { Kidney } \\
\text { Pancreas } \\
\text { Lungs } \\
\text { Depot fat }\end{array}\right.\end{array}$ & $\begin{array}{l}122 \\
122 \\
122 \\
122 \\
122 \\
122\end{array}$ & 85 \\
\hline $\begin{array}{l}\text { Tissues and organs } \\
\text { growing more rapidly } \\
\text { than the body as a } \\
\text { whole }\end{array}$ & $\left\{\begin{array}{l}\text { Heart } \\
\text { Alimentary tract } \\
\text { Skeleton } \\
\text { Nervous tissue }\end{array}\right.$ & $\begin{array}{l}125 \\
125 \\
128 \\
130\end{array}$ & $\begin{array}{l}87 \\
89 \\
90\end{array}$ \\
\hline $\begin{array}{l}\text { Organs growing less } \\
\text { rapidly than the body } \\
\text { as a whole }\end{array}$ & $\left\{\begin{array}{l}\text { Liver } \\
\text { Spleen } \\
\text { Thymus }\end{array}\right.$ & $\begin{array}{r}94 \\
\text { II I } \\
\text { I } 10\end{array}$ & $\begin{array}{l}65 \\
77 \\
76\end{array}$ \\
\hline
\end{tabular}

the retardation of foetal growth was not uniform. The underweight lamb produced by the undernourished ewe may thus be regarded not simply as a premature lamb, but as a lamb in which some tissues are more and some less premature than others. 
The pattern of morphological development has been disturbed. The same conclusion was reached by Verges (1939) in similar experiments with sheep.

If these underweight lambs may be regarded as morphologically premature ones, it is reasonable to suppose that in their physiological reactions they would exhibit some degree of immaturity similar to those shown by the premature human infant. On this aspect knowledge is limited, and, apart from the practical observations that the lambs lack vigour and strength, there appear to have been no studies specifically designed to examine this aspect. One can postulate that homeothermic adjustments will be seriously impaired, that the integrative action of their nervous systems will be incompletely developed, and defects of erythropoiesis, blood circulation, and the absorption of food from the gut might be expected. It is a reasonable hypothesis that much of the mortality of the newborn from undernourished mothers can be attributed to an immaturity of their ability to adapt themselves to an independent life.

\section{Pregnancy toxaemia}

Pregnancy toxaemia, in which ewes develop marked ketosis, become partially blind, ataxic, and eventually become comatose and die, is a disease referable in large part to the nutritional status of the ewe during the last few weeks of pregnancy. It is most common in ewes bearing twin lambs. It appears to be more common in lowland than in hill flocks, and one estimate suggests that its incidence causes an economic loss of $f_{\mathrm{I}} \mathrm{I}-2$ million in Britain and $f_{\mathrm{f}} \mathrm{O}$ million in the Commonwealth (Parry, 1955). Frazer, Godden, Snook \& Thomson (1938-9, 1939-40) showed that ketosis could be produced by feeding a diet deficient in calories to pregnant ewes. Gill \& Thomson (1954-5) and Parry (1956) have confirmed this work and shown that the incidence of pregnancy toxaemia is certainly associated with low nutrition during the latter part of pregnancy, but that a prerequisite is a high level of feeding before the period of undernutrition. In ewes kept at a low level of nutrition throughout pregnancy the incidence of the disease was low. Only when fat ewes were underfed during the last 5 weeks of pregnancy did the disease occur. Underfeeding of fat ewes before this time had no effect. This effect of fatness of the ewe before she is underfed accounts for the low incidence of the disease on hill farms, where the ewes are rarely in fat condition before the severe winter storms come, and the higher incidence in the fatter ewes in lowland flocks.

\section{Lactation and nutrition in pregnancy}

Practical trials with cattle have shown that by increasing the nutritional level in the last 6 weeks of pregnancy, milk production in the early part of the subsequent lactation can be increased (Blaxter, I944; Campbell \& Flux, I948; Lees, McMeekan \& Wallace, 1948; Flux, I950; Bonnier, 1946). The same is true of the ewe (Wallace, I948; Barnicoat, Logan \& Grant, 1949; Munro, 1955). The increases in milk yield obtained vary according to the nutritional conditions during lactation, but usually the initial advantage is maintained throughout and, in cattle, increases in yield of 
over $30 \%$ have been obtained. In ewes differences in milk yield of several-fold have been noted, but in these experiments the nutritional deprivation in the poorest milkers was extremely severe. In animals given more food during late pregnancy udder development is increased. Dissection studies by Wallace with ewes have shown that the weight of the udder in underfed animals is only about a third of that of more normally fed ones.

\section{Other effects of nutrition in pregnancy}

In the pregnant ewe, particularly during winter, there is a marked reduction in wool growth (Ferguson, Carter \& Hardy, i949). Under extreme conditions a break in the fleece may occur, that is follicles shed their fibres and involute, and those that do remain in production produce shorter and thinner fibres. Recent work suggests that here the physiological mechanism is temporary hyperactivity of the adrenal cortex (Lindner \& Ferguson, 1956). Both cold and gestation increase adrenocortical activity, and it is possible that undernutrition and other environmental stresses exert their effect on the fleece in this way. The importance of wool for maintaining the thermal equilibrium of the pregnant ewe under cold, exposed situations is obvious, and here nutrition plays a very large part.

\section{General}

In discussing the effects of differences in the energy supply to the pregnant animal the terms 'low plane' and 'high plane' have been used to make distinctions between diets. This use of relative extremes is a matter of convenience, but it must be emphasized that the effects noted and discussed are not the all-or-none effects which accompany many vitamin or mineral deficiencies of pregnant stock. Rather there is a continuous gradation of effect from the lowest to the highest nutritional plane.

This raises the question of what criteria could be used to judge the optimal energy supply for the pregnant animal. A diet that results in minimal maternal and infantile mortality and morbidity, one that results in maximal subsequent growth and development of the offspring, the most rapid recovery of the dam after parturition and one that results in an uneventful resumption of the normal reproductive cycle would seem reasonable, and the criteria adequate. These criteria would undoubtedly place restrictions both on overt undernutrition and on the superfattening of pregnant animals. Farm practice, however, does not accept such criteria, since the end-result of farming is an economic one. The criterion adopted in farming practice for judging whether a diet is optimal or not is simply whether the monetary return resulting from improvement of the ration is greater than the cost of making the improvement. On some remote hill farms the considerable increase in lamb output per 100 acres which would accrue as a result of improvement in the nutrition of the pregnant ewe would not cover the financial cost of the provision of food. In contrast, on some dairy farms it has proved economically profitable to use very high 
levels of feeding in the latter part of pregnancy to ensure high levels of milk production in the following lactation. It is a very salutary thought that in the instance of farm stock economic factors determine the unborn animal's chance of survival.

\section{REFERENCES}

Asdell, S. A. (r952). Congr. int. Physiol. Réprod. anim. Ir. Copenhagen, 2, p. 7.

Barnicoat, C. R., Logan, A. G. \& Grant, A. I. (I949). F. agric. Sci. 39, 44.

Blaxter, K. L. (1944). F. agric. Sci. 34, 27.

Blaxter, K. L., Graham, N. McC. \& Wainman, F. W. (1956). Unpublished.

Bonnier, G. (1946). K. LantbrAkad. Handl., Stockh., 85, 221.

Bonsma, J. C. (1949). F. agric. Sci. 39, 204.

Braude, R., Clarke, P. M. \& Mitchell, K. G. (1954-5). J. agric. Sci. 45, 19.

Braude, R. \& Walker, D. M. (1949). F. agric. Sci. 39, r 56.

Campbell, I. L. \& Flux, D. S. (1948). Proc. N.Z. Soc. Anim. Prod. p. 6r.

Du Toit, P. J. \& Bisschop, J. H. R. (1929). Rep. vet. Res. S. Afr. 15, 1059.

Ferguson, K. A., Carter, H. B. \& Hardy, M. H. (1949). Aust. F. sci. Res. B, 2, 42.

Flux, D. S. (1950). 7. agric. Sci. 40, 177.

Frazer, A. H. H., Godden, W., Snook, L. C. \& Thomson, W. (1938-9). F. Physiol. 94, 346.

Frazer, A. H. H., Godden, W., Snook, L. C. \& Thomson, W. (1939-40). F. Physiol. 97, 20.

Gill, J. C. \& Thomson, W. (1954). Brit, agric. Bull. 6, 154.

Gill, J. C. \& Thomson, W. (1954-5). Y. agric. Sci. 45, 229.

Gordon, J. G. \& Tribe, D. E. (1951). F. agric. Sci. 41, 187.

Gracey, J. F. (1955). Vet. Rec. 67, 984 .

Hafez, E. S. E. (1952). F. agric. Sci. 42, 189.

Hammond, J. (1932). Growth and the Development of Mutton Qualities in the Sheep. Edinburgh: Oliver and Boyd.

Joubert, D. M. (1954-5). J. agric. Sci. 45, 164.

Lees, F. T., McMeekan, C. P. \& Wallace, L. R. (1948). Proc. N.Z. Soc. Anim. Prod. p. 60.

Lindner, H. R. \& Ferguson, K. A. (1956). Nature, Lond., 177, 188.

Mäkelä, A. (1956). Suom. Maataloust. Seur. Fulk. 85, I.

McTurk, R. (1843). Trans. Highl. agric. Soc. Scot. 2nd ser. 8, 631 .

Munro, J. (1955). F. agric. Sci. 46, 131.

Paloheimo, L. (1944). Suom. Maataloust. Seur. Fulk. 56, 5.

Parry, H. B. (1955). Proc. Brit. Soc. Anim. Prod. p. 52.

Parry, H. B. (1956). Nature, Lond., r77, 288.

Perry, J. S. (1956). F. agric. Sci. 47, 332 .

Sellers, K. C. \& Leech, F. B. (1955). F. agric. Sci. 46, go.

Smith, H. R. (1954). Report of the Department of Health for Scotland, 1953 [Cmd. 9107].

Thomson, A. M. \& Thomson, W. (1948-9). Brit. $\mathcal{F}$. Nutr. 2, 290.

Verges, J. B. (1939). Yearb. Suffolk Sheep Soc. Ipswich.

Wallace, L. R. (1948). 7. agric. Sci. 38, 93 .

Wallace, L. R. (1954-5). J. agric. Sci. 45, 60.

Williams, S. M. (1954-5). f. agric. Sci. 45, 202.

Withers, F. W. (1952). Brit. vet. $\mathcal{F}$. 108, 315.

Withers, F. W. (1955). Vet. Rec. 67, 605. 